\title{
Thiomicrospira halophila sp. nov., a moderately halophilic, obligately chemolithoautotrophic, sulfur-oxidizing bacterium from hypersaline lakes
}

Correspondence
Dimitry Yu. Sorokin
soroc@inmi.host.ru or
D.Y.Sorokin@tnw.tudelft.nl

\author{
Dimitry Yu. Sorokin, ${ }^{1,2}$ Tatjana P. Tourova, ${ }^{1}$ Tatjana V. Kolganova, ${ }^{3}$ \\ Elizaveta M. Spiridonova, ${ }^{4}$ Ivan A. Berg ${ }^{4}$ and Gerard Muyzer ${ }^{2}$ \\ ${ }^{1}$ Winogradsky Institute of Microbiology, Russian Academy of Sciences, Prospect 60-let \\ Octyabrya 7/2, 117811 Moscow, Russia \\ ${ }^{2}$ Department of Biotechnology, Delft University of Technology, Julianalaan 67, 2628 BC Delft, \\ The Netherlands \\ ${ }^{3}$ Bioengineering Center, Russian Academy of Sciences, Moscow, Russia \\ ${ }^{4}$ Department of Microbiology, Faculty of Biology, Moscow State University, Moscow, Russia
}

\begin{abstract}
Enrichments at $2 \mathrm{M} \mathrm{NaCl}$ and $\mathrm{pH} 7 \cdot 5-8$, with thiosulfate or sulfide as electron donor, inoculated with sediments from hypersaline chloride-sulfate lakes of the Kulunda Steppe (Altai, Russia) resulted in the domination of two different groups of moderately halophilic, chemolithoautotrophic, sulfur-oxidizing bacteria. Under fully aerobic conditions with thiosulfate, bacteria belonging to the genus Halothiobacillus dominated while, under microaerophilic conditions, a highly motile, short vibrio-shaped phenotype outcompeted the halothiobacilli. Three genetically and phenotypically highly similar vibrio-shaped isolates were obtained in pure culture and one of them, strain $\mathrm{HL} 5^{\top}$, was identified as a member of the Thiomicrospira crunogena cluster by $16 \mathrm{~S}$ rRNA gene sequencing. The new isolates were able to grow with thiosulfate as electron donor within a broad salinity range from 0.5 to $3.5 \mathrm{M} \mathrm{NaCl}$ with an optimum at $1.5 \mathrm{M}$ and within a $\mathrm{pH}$ range from 6.5 to 8.5 with an optimum at $\mathrm{pH} 7 \cdot 5-7 \cdot 8$. Comparative analysis of ribulose-1,5-bisphosphate carboxylase/ oxygenase (RuBisCO) gene sequences demonstrated that strain $\mathrm{HL}^{\top}$ possessed two genes, $c b b L-1$ and $c b b L-2$, of the form I RuBisCO and a cbbM gene of the form II RuBisCO, similar to the other members of the Thiomicrospira crunogena cluster. On the basis of phenotypic and genetic comparison, the new halophilic isolates are proposed to be placed into a novel species, Thiomicrospira halophila sp. nov. (type strain $\mathrm{HL} 5^{\top}=\mathrm{DSM} 15072^{\top}=\mathrm{UNIQEM} \mathrm{U} 221^{\top}$ ).
\end{abstract}

Although hypersaline environments, such as inland salt lakes and sea salterns, are traditionally regarded as the domain of heterotrophic haloarchaea, which grow optimally at $\mathrm{NaCl}$ concentrations above $3 \mathrm{M}$ (Oren, 2002), this is mostly true of the brines. In the sediments, which are separated from the brine by a thick salt crust, the microbial communities are more complex and include halophilic eubacteria of different physiology. In particular, halophilic sulfate-reducing bacteria can be active in these environments up to saturating salt concentrations (Ollivier et al., 1994; Sørensen et al., 2004). The latter can be a condition

\footnotetext{
Abbreviations: RSCU, relative synonymous codon usage; RuBisCO, ribulose-1,5-bisphosphate carboxylase/oxygenase; SOB, sulfur-oxidizing bacterium.

The GenBank/EMBL/DDBJ accession numbers for the 16S rRNA and $c b b$ gene sequences of strain $\mathrm{HL} 5^{\top}$ are DQ390450 and DQ390451DQ390453, respectively.
}

for development of their counterpart, halophilic sulfuroxidizing bacteria (SOB). Among the chemolithotrophic bacteria, SOB have a good chance to adapt to extreme conditions, such as high salt, owing to the high energy yield available during complete oxidation of sulfide/thiosulfate to sulfate (Oren, 1999).

The first and so far only neutrophilic, halophilic SOB able to grow at very high salt concentrations, up to $4 \mathrm{M} \mathrm{NaCl}$, was discovered 15 years ago in an Australian hypersaline lake (Wood \& Kelly, 1991) and is currently known as Halothiobacillus halophilus (Kelly \& Wood, 2000). The organism belongs to the high-salt-tolerant moderate halophiles, with an optimum salt concentration for growth around $1 \mathrm{M}$. Since that time, no attempts have been made to peer more thoroughly into the diversity of halophilic SOB in hypersaline habitats. Our current research on haloalkaliphilic SOB inhabiting soda lakes, however, has demonstrated the widespread potential of SOB to grow at very high 
concentrations of sodium carbonates (Sorokin \& Kuenen, 2005). This prompted us to start analogous research on the diversity of $\mathrm{SOB}$ in hypersaline chloride-sulfate inland lakes and salterns with neutral $\mathrm{pH}$.

The Kulunda Steppe (Altai, Russia) harbours numerous salt lakes with a total salt content from 10 to $38 \%$, a pH range of $7 \cdot 0-8 \cdot 5$ and with $\mathrm{Na}^{+}, \mathrm{Cl}^{-}$and $\mathrm{SO}_{4}^{2-}$ as the dominant ions in the brines. Samples were obtained from the top $10 \mathrm{~cm}$ of sediment with overlying brine water from 20 lakes and were grouped into three categories according to the salinity.

Halophilic SOB were enriched and isolated in pure culture using the following mineral base medium $\left(\mathrm{g} \mathrm{l}^{-1}\right)$ : $\mathrm{NaCl}, 120$; $\mathrm{K}_{2} \mathrm{HPO}_{4}, 1 \cdot 5 ;\left(\mathrm{NH}_{4}\right)_{2} \mathrm{SO}_{4}, 0 \cdot 5$. The $\mathrm{pH}$ was adjusted to $7 \cdot 2$. After sterilization, the medium was supplemented with $2 \mathrm{mM} \mathrm{MgCl}_{2} \cdot 6 \mathrm{H}_{2} \mathrm{O}, 1 \mathrm{ml}$ trace metal solution $\mathrm{l}^{-1}$ (Pfennig \& Lippert, 1966) and 20-50 $\mathrm{mM} \mathrm{NaHCO} 3$ (from a $1 \mathrm{M}$ filter-sterilized solution). The final $\mathrm{pH}$ was $7 \cdot 5-7 \cdot 8$ and the incubation temperature was $25^{\circ} \mathrm{C}$. Two types of enrichments were performed. Enrichments with thiosulfate as substrate $(20 \mathrm{mM})$ were incubated in sealed $100 \mathrm{ml}$ serum bottles with $10 \mathrm{ml}$ medium under fully aerobic conditions (gas phase, air; rotary shaker at 150 r.p.m.) and under microaerophilic conditions with $10 \mathrm{ml}$ medium in $250 \mathrm{ml}$ bottles at $2 \% \mathrm{O}_{2}$ (static). The second type of enrichment was based on gradient cultivation (Nelson \& Jannasch, 1983) in $50 \mathrm{ml}$ glass cylinders, whereby sulfide, as substrate, was diffusing upward from the bottom $2 \%(\mathrm{w} / \mathrm{v})$ agar layer $(10 \mathrm{ml}, 0 \cdot 1 \mathrm{mmol} \mathrm{Na} 2 \mathrm{~S}$ ) overlaid by $30 \mathrm{ml}$ of the abovementioned mineral medium containing one-tenth of the amount of trace elements and $0 \cdot 2 \%(\mathrm{w} / \mathrm{v})$ agarose. Oxygen was diffusing downward from the $10 \mathrm{ml}$ headspace. $\mathrm{SOB}$ usually developed within a thin layer approximately $1 \mathrm{~cm}$ below the surface of the top medium layer. The isolation strategy included several 1:100 transfers to stabilize the cultures, followed by serial dilutions and plating onto solid medium with the same composition (for thiosulfate enrichments). The plates were incubated either in plastic bags (aerobic) or in closed jars under $2 \% \mathrm{O}_{2}$ (microaerophilic). For sulfide-gradient cultures, dilution series were performed in $20 \mathrm{ml}$ stoppered tubes with the proportions of different layers similar to that used in the cylinders. Growth was monitored by measuring the $\mathrm{OD}_{600}$ (in case of intermediate sulfur formation, it was removed by centrifugation at 3000 r.p.m. for $1 \mathrm{~min}$ ) and by monitoring thiosulfate consumption and $\mathrm{pH}$. The $\mathrm{pH}$ was maintained above $\mathrm{pH} 7$ by periodic addition of $\mathrm{NaHCO}_{3}$. Sulfur compounds (thiosulfate, sulfide, tetrathionate and elemental sulfur), protein concentration and respiration rates of washed cells were measured as described previously (Sorokin et al., 2001). Phase-contrast photomicrographs were obtained using a Zeiss Axioplan Imaging 2 microscope. For electron microscopy, cells were fixed with glutaraldehyde (final, $3 \% \mathrm{v} / \mathrm{v})$ and positively contrasted with $1 \%(\mathrm{w} / \mathrm{v})$ uranyl acetate. The isolation of DNA and subsequent determination of the $\mathrm{G}+\mathrm{C}$ content of the DNA and DNA-DNA hybridization were performed by the thermal denaturation/ reassociation technique (Marmur, 1961; De Ley et al., 1970).

The 16S rRNA genes were selectively amplified using general bacterial primers and the PCR products were purified from low-melting-temperature agarose using a Wizard PCR Prep kit (Promega) according to the manufacturer's instructions. To amplify bacterial genes of RuBisCO form I and form II large subunit ( $c b b L$ and $c b b M$, respectively), specially designed and previously tested primer pairs were employed (Spiridonova et al., 2004). Purified PCR fragments were cloned into the pGEM-T vector (Promega) using competent cells of Escherichia coli DH5 $\alpha$ for transformation. Plasmid DNA was extracted and purified using the Wizard MiniPrep kit (Promega) according to the manufacturer's recommendations. Clones containing appropriately sized inserts were sequenced from universal M13 forward and reverse primers. Sequencing was performed using a Big Dye Terminator version 3.1 sequencing reaction kit with an $\mathrm{ABI} 3730 \mathrm{DNA}$ automatic sequencer (Applied Biosystems).

Preliminary phylogenetic analysis of the new sequences was done with the NCBI BLAST server (http://www.ncbi.nlm.nih.

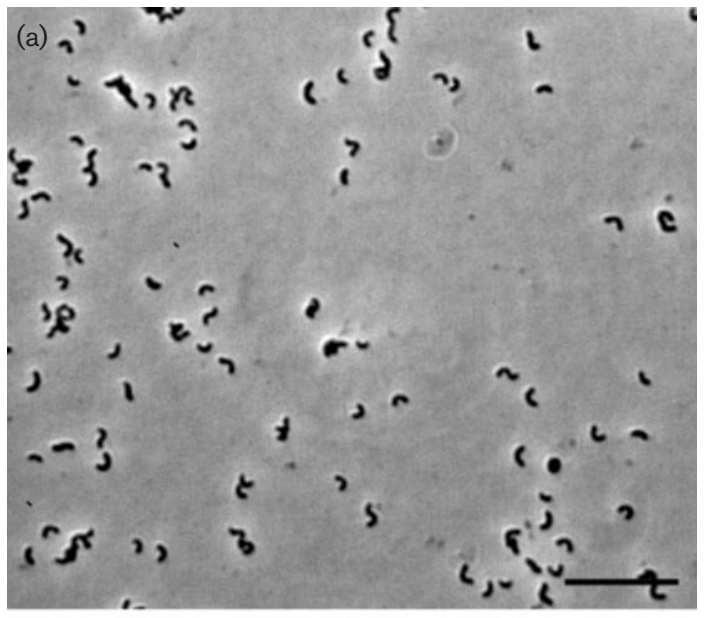

(b)

Fig. 1. Cell morphology of strain $\mathrm{HL} 5^{\top}$ grown at $2 \mathrm{M} \mathrm{NaCl}$ with thiosulfate. (a) Phase-contrast photomicrograph (bar, $10 \mu \mathrm{m})$. (b) Electron photomicrograph of positively stained cell (bar, $1 \mu \mathrm{m}$ ). 
gov/blast/). Nucleotide and inferred amino acid sequences were aligned with sequences from GenBank using CLUSTAL W. Phylogenetic trees were reconstructed using the neighbour-joining algorithm within the TREECONW program package (Van de Peer \& De Wachter, 1994).

Relative synonymous codon usage (RSCU) values of the RuBisCO genes were calculated using CodonW software (http://www.molbiol.ox.ac.uk/cu). To investigate major trends in codon usage in different species, CodonW was used to carry out a correspondence analysis. This resulted in a point in the codon space for each species, the positions of which sometimes suggested codon usage bias.

Aerobic enrichments with thiosulfate at $2 \mathrm{M} \mathrm{NaCl}$ resulted in rapid growth of rod-shaped, motile SOB. From these cultures, colonies of the rod-shaped SOB could be easily obtained on mineral plates with thiosulfate and two pure cultures were identified by $16 \mathrm{~S}$ rRNA gene sequencing as members of the genus Halothiobacillus (data not shown). However, in enrichments with thiosulfate under micro-oxic conditions and, especially in sulfide-oxygen gradient cultures, small and extremely motile vibrios developed more rapidly than halothiobacilli. Unfortunately, they did not readily form colonies on plates. As a consequence, the colony approach always resulted in the dominance of halothiobacilli, even if they were minor components in the liquid cultures. Only after several dilution series, when the vibrio phenotype became highly enriched, did tiny, sulfurcontaining colonies appear on thiosulfate plates under micro-oxic conditions after $2-3$ weeks incubation. Two pure cultures were obtained from single colonies originating from thiosulfate enrichments (lake salinity ranges 100-140 and 200-240 $\mathrm{g} \mathrm{l}^{-1}$ ) and one culture after serial dilutions of $\mathrm{a}-1$ ). The strains were designated HL $5^{\mathrm{T}}$, HL 8 (isolated with

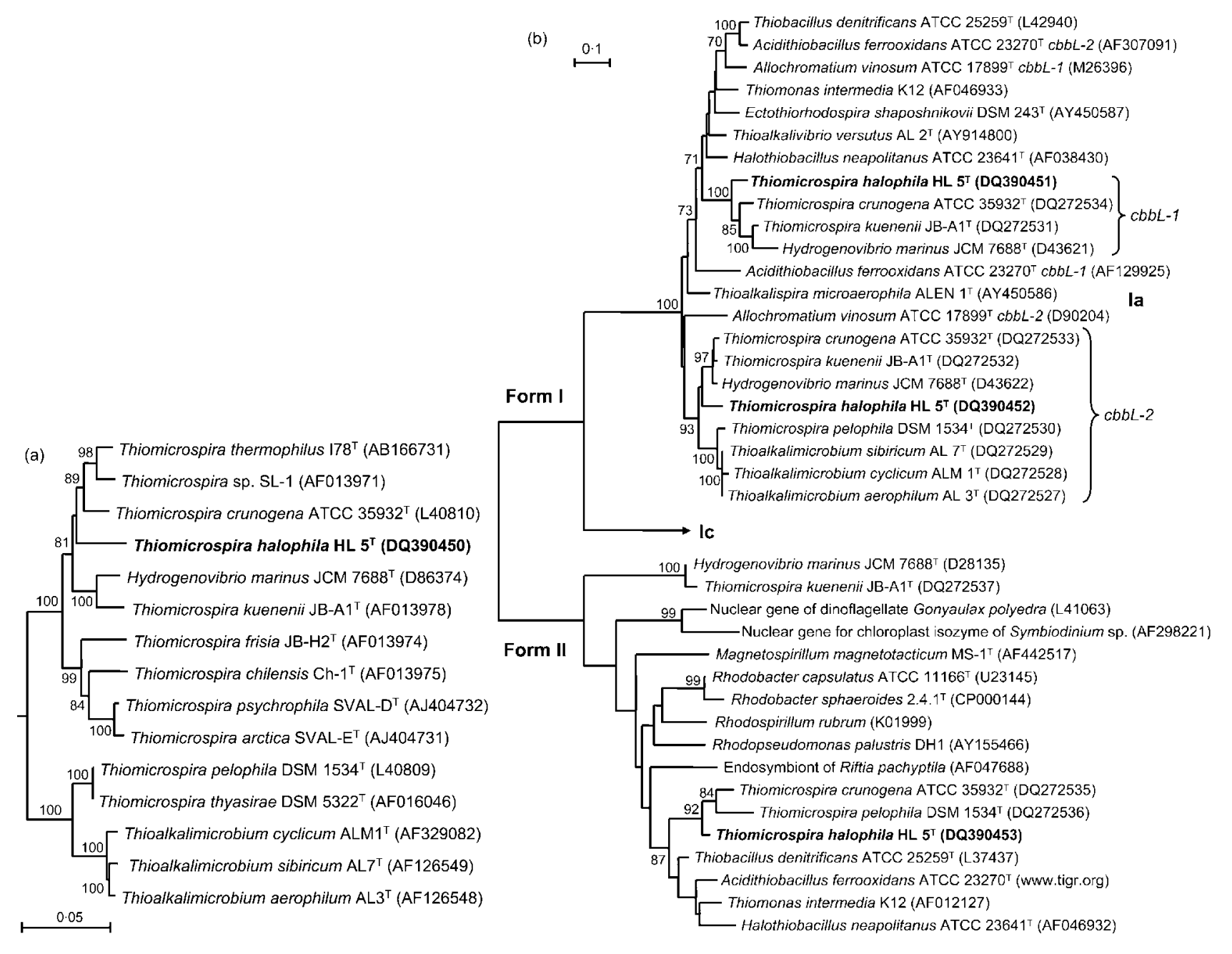

Fig. 2. Phylogenetic position of halophilic sulfur-oxidizing bacterium strain $\mathrm{HL} 5^{\top}$ within the Gammaproteobacteria based on analysis of 16S rRNA gene sequences (a) and translated amino acid sequences of $c b b$ genes (b). Tree topology and evolutionary distances are given by the neighbour-joining method with Jukes \& Cantor (for nucleotide sequences) and Poisson (for amino acid sequences) corrections. Numbers at nodes indicate percentages of bootstrap values for the clade of this group in 1000 replications. 
thiosulfate) and HLgr 1 (isolated from sulfide gradient culture). Genetic comparison (DNA-DNA hybridization) demonstrated a high level of relatedness (85-95\%) between the isolates. Therefore, subsequent experiments were performed with the representative strain $\mathrm{HL} 5^{\mathrm{T}}$.

All three isolates were small vibrios, highly motile with a single polar flagellum (Fig. 1). Despite the fact that they outcompeted halothiobacilli under micro-oxic conditions, growth of pure cultures was not inhibited under fully aerobic conditions with thiosulfate provided that the $\mathrm{pH}$ was kept above $6 \cdot 5$ by the addition of $\mathrm{NaHCO}_{3}$. In that case, all thiosulfate was oxidized to sulfate. At lower $\mathrm{pH}$, thiosulfate was partially converted to elemental sulfur. Polythionates (tetra- and trithionate) were not detected among the products. Cells of strain $\mathrm{HL} 5^{\mathrm{T}}$, grown with thiosulfate, were capable of oxidation of sulfide, thiosulfate and elemental sulfur (the latter supplied as a saturated solution in acetone) at maximum rates of 950, 440 and $90 \mathrm{nmol} \mathrm{O}_{2}$ (mg protein $)^{-1} \mathrm{~min}^{-1}$, respectively. Strain $\mathrm{HL}$ $5^{\mathrm{T}}$ grew with thiosulfate at $\mathrm{NaCl}$ concentrations between $0 \cdot 5$ and $3.5 \mathrm{M}$ with an optimum at $1.5 \mathrm{M}$, which qualifies this bacterium as an extremely halotolerant moderate halophile. At $2 \mathrm{M} \mathrm{NaCl}$ with thiosulfate as substrate, the bacterium grew at temperatures from 20 to $43{ }^{\circ} \mathrm{C}$ with an optimum at $30^{\circ} \mathrm{C}$ (lower temperatures were not tested).
Thiosulfate-oxidizing activity in washed cells was maximal at $0.75-1.5 \mathrm{M} \mathrm{NaCl}$. At salt concentrations below $0.5 \mathrm{M}$, the cells lysed, turning into spheroplasts. Growth with thiosulfate at $2 \mathrm{M} \mathrm{NaCl}$ was possible within the $\mathrm{pH}$ range $6 \cdot 5-8 \cdot 5$, with an optimum at $\mathrm{pH} 7 \cdot 5-7 \cdot 8$. Under optimal growth conditions $\left(1.5 \mathrm{M} \mathrm{NaCl}, \mathrm{pH} 7 \cdot 5,30^{\circ} \mathrm{C}\right)$, the experimentally measured specific growth rate and growth yield on thiosulfate were $0.25 \mathrm{~h}^{-1}$ and $3.5 \mathrm{mg}$ protein $\mathrm{mmol}^{-1}$, respectively.

Phylogenetic analysis based on sequencing of the 16S rRNA gene placed strain $\mathrm{HL} 5^{\mathrm{T}}$ in the Gammaproteobacteria as a member of the Thiomicrospira crunogena cluster (Fig. 2a). Currently, this group includes eight species with validly published names, many uncharacterized isolates from various marine habitats (Brinkhoff et al., 2005) and a single hydrogen-utilizing bacterium, Hydrogenovibrio marinus (Nishihara et al., 1991). The level of 16S rRNA gene sequence similarity between strain $\mathrm{HL} 5^{\mathrm{T}}$ and other species of this cluster ranged from $93 \cdot 7$ to $96 \cdot 2 \%$, whereas the similarity with species of the Thiomicrospira pelophila cluster (including the members of the genus Thioalkalimicrobium) did not exceed $93 \%$.

By using a specific primer set for the RuBisCO genes, encoding the key enzyme of autotrophic carbon assimilation,

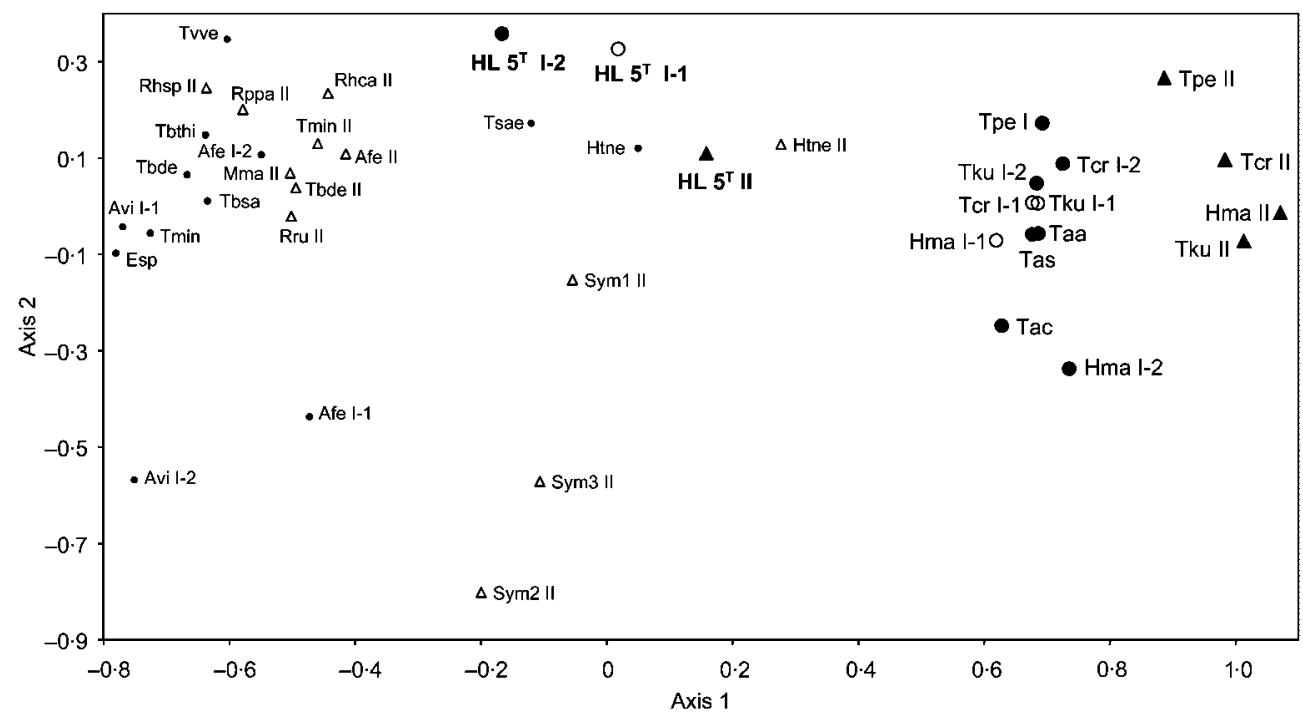

Fig. 3. Correspondence analysis of RSCU (codon usage) in Thiomicrospira species for cbb (LM) genes. Large filled circles indicate $c b b L-2$ genes of the studied group (I-2), open circles indicate $c b b L-1$ genes of the studied group (I-1), small filled circles indicate $c b b L$ genes of all other bacteria, filled triangles indicate $c b b M$ genes of the studied group (II) and open triangles indicate $c b b M$ genes of all other micro-organisms (II). Taxa are abbreviated as: Taa, Thioalkalimicrobium aerophilum; Tas, Thioalkalimicrobium sibiricum; Tac, Thioalkalimicrobium cyclicum; Tcr, Thiomicrospira crunogena; Tku, Thiomicrospira kuenenii; Tpe, Thiomicrospira pelophila; Hma, Hydrogenovibrio marinus; Afe, Acidithiobacillus ferrooxidans; Tbde, Thiobacillus denitrificans; Htne, Halothiobacillus neapolitanus; Tmin, Thiomonas intermedia; Tsae, Thioalkalispira microaerophila; Avi, Allochromatium vinosum; Tvve, Thioalkalivibrio versutus; Esp, Ectothiorhodospira shaposhnikovii; Rru, Rhodospirillum rubrum; Mma, Magnetospirillum magnetotacticum; Rppa, Rhodopseudomonas palustris; Rhca, Rhodobacter capsulatus; Rhsp, Rhodobacter sphaeroides; Sym1, Riftia pachyptila endosymbiont; Sym2, Symbiodinium sp. (dinoflagellate); Sym3, Gonyaulax polyedra (dinoflagellate). Genes are plotted at their coordinates on the two axes produced by the analysis. 
it was shown that strain HL $5^{\mathrm{T}}$ possessed two different $c b b L$ genes of the 'green-like' form I and a $c b b M$ gene of the form II of this enzyme, similar to the other species in the Thiomicrospira crunogena cluster, such as Hydrogenovibrio marinus (Yoshizawa et al., 2004), Thiomicrospira crunogena and Thiomicrospira kuenenii (Tourova et al., 2006). However, the $\mathrm{G}+\mathrm{C}$ content in the genome of all three halophilic isolates was $56 \cdot 1-57 \cdot 1 \mathrm{~mol} \%$, which is $5-15 \mathrm{~mol} \%$ higher than in the Thiomicrospira crunogena group $(39 \cdot 2-51 \cdot 7$ mol\%). DNA-DNA hybridization of the new isolates with Thiomicrospira sp. strain SL 1, the strain with the highest $\mathrm{G}+\mathrm{C}$ content within the Thiomicrospira crunogena lineage $(51.7 \mathrm{~mol} \%)$ which originated from Solar Lake, Sinai, Egypt (Brinkhoff \& Muyzer, 1997), and with Thiomicrospira crunogena DSM $12353^{\mathrm{T}}$ was below $20 \%$. Nevertheless, analysis of both $16 \mathrm{~S}$ rRNA gene sequences (Fig. 2a) and translated amino acid sequences of the RuBisCO genes (Fig. 2b) firmly placed strain HL $5^{\mathrm{T}}$ into the Thiomicrospira crunogena group.

The $\mathrm{G}+\mathrm{C}$ content of the $c b b$ genes revealed a strong linear correlation with the genomic $\mathrm{G}+\mathrm{C}$ content, which is common (Muto \& Osawa, 1987). The large differences in the $\mathrm{G}+\mathrm{C}$ content of the total DNA between the new isolates and other members of the Thiomicrospira crunogena cluster were not an artefact, since the obtained fragments of RuBisCO genes from strain HL $5^{\mathrm{T}}$ also had a similarly high $\mathrm{G}+\mathrm{C}$ content. The total $\mathrm{G}+\mathrm{C}$ content for the $c b b$ genes of this strain was $54 \cdot 1-58 \cdot 7 \mathrm{~mol} \%$, compared with $45 \cdot 1-48 \cdot 9 \mathrm{~mol} \%$ for the corresponding genes of phylogenetically related species. Comparison of codon usage in the RuBisCO genes between strain HL $5^{\mathrm{T}}$ and Thiomicrospira species using RSCU data identified the major trends (Fig. 3): axis 2 is associated with the $\mathrm{G}+\mathrm{C}_{3}$ content (in the third position of codons) (Musto et al., 1998) and axis 1 shows the frequency of codons ending in $\mathrm{C}$ or $\mathrm{U}$ versus A or G (Fennoy \& Bailey-Serres, 1993). The codon usage of all Thiomicrospira species was typical of A/Tbiased micro-organisms, in which codons with an $\mathrm{A}$ or $\mathrm{T}$ in the third position are used preferentially (Ohtaka \& Ishikawa, 1993). In contrast, the codon usage of strain HL $5^{\mathrm{T}}$ was typical of G/C-biased bacteria. Based on codon usage, the closest neighbours of the strain HL $5^{\mathrm{T}}$ were (halo)alkaliphilic sulfur-oxidizing gammaproteobacteria such as Thioalkalispira microaerophila and Halothiobacillus neapolitanus, with a similar $\mathrm{G}+\mathrm{C}$ content of their genomic DNA $(56 \cdot 0 \mathrm{~mol} \%)$ and the two types of RuBisCO genes $(54 \cdot 9-55 \cdot 5 \mathrm{~mol} \%)$.

On the basis of phenotypic and genetic comparison, the new halophilic SOB from hypersaline lakes are proposed to be assigned to a novel species of the genus Thiomicrospira, Thiomicrospira halophila sp. nov. Comparative properties of the new isolates and Thiomicrospira species with validly published names are presented in Table 1.

\section{Description of Thiomicrospira halophila sp. nov.}

Thiomicrospira halophila (ha.lo'phi.la. Gr. n. hals salt; Gr. adj. philos loving; N.L. fem. adj. halophila salt-loving).

Cells are Gram-negative vibrios $(0 \cdot 3-0 \cdot 5 \times 1-2 \mu \mathrm{m})$, highly motile due to a single polar flagellum. Colonies on thiosulfate agar at 1-2 $\mathrm{M} \mathrm{NaCl}$ reach a maximum diameter of $1 \mathrm{~mm}$ and are convex, circular and silver-white (because of sulfur accumulation). Strictly aerobic, with a tendency for microaerophilism. Grows chemolithoautotrophically with thiosulfate and sulfide, oxidizing them to sulfate with elemental sulfur as an intermediate. Does not produce or oxidize polythionates. Autotrophic growth with thiosulfate is possible within the range of $0 \cdot 5-3 \cdot 5 \mathrm{M} \mathrm{NaCl}$ (optimum

Table 1. Comparative characteristics of strain $\mathrm{HL} 5^{\top}$ (Thiomicrospira halophila sp. nov.) and related species

Species: 1, Thiomicrospira halophila; 2, Thiomicrospira crunogena (data from Brinkhoff et al., 2005); 3, Thiomicrospira chilensis (Brinkhoff et al., 2005); 4, Thiomicrospira frisia (Brinkhoff et al., 2005); 5, Thiomicrospira kuenenii (Brinkhoff et al., 2005); 6, Thiomicrospira arctica (Knittel et al., 2005); 7, Thiomicrospira psychrophila (Knittel et al., 2005); 8, Thiomicrospira thermophila (Takai et al., 2004); 9, Hydrogenovibrio marinus (Nishihara et al., 1991). ND, Not determined.

\begin{tabular}{|c|c|c|c|c|c|c|c|c|c|}
\hline Characteristic & 1 & 2 & 3 & 4 & 5 & 6 & 7 & 8 & 9 \\
\hline DNA G $+C$ content $(\mathrm{mol} \%)$ & $56 \cdot 6$ & $44 \cdot 2$ & $49 \cdot 9$ & $39 \cdot 6$ & $42 \cdot 4$ & $42 \cdot 4$ & $42 \cdot 5$ & $43 \cdot 8$ & $44 \cdot 1$ \\
\hline $\begin{array}{l}\text { Optimum } \mathrm{NaCl} \text { concentration } \\
\text { (M) }\end{array}$ & $1 \cdot 50$ & ND & $0 \cdot 47$ & $0 \cdot 47$ & $0 \cdot 47$ & $0 \cdot 25$ & $0 \cdot 25$ & $0 \cdot 30$ & $0 \cdot 50$ \\
\hline $\mathrm{S}_{8}$ as intermediate & + & + & + & - & - & + & + & + & + \\
\hline $\mathrm{H}_{2}$ as electron donor & - & - & - & - & - & - & - & - & + \\
\hline Growth below $0{ }^{\circ} \mathrm{C}$ & - & - & - & - & - & + & + & - & + \\
\hline Growth at $>50^{\circ} \mathrm{C}$ & - & - & - & - & - & - & - & + & - \\
\hline
\end{tabular}


$1 \cdot 5 \mathrm{M})$ and at $\mathrm{pH} 6 \cdot 5-8 \cdot 5$ (optimum $\mathrm{pH} 7 \cdot 5-7 \cdot 8$ ). Inorganic carbon is assimilated through the Calvin cycle. Possesses three different RuBisCO genes. Differs from the other Thiomicrospira species by its high salt tolerance and much higher $\mathrm{G}+\mathrm{C}$ content of genomic DNA. Represented by three closely related strains isolated from hypersaline inland lakes in south-western Siberia (Altai, Russia) with DNA $\mathrm{G}+\mathrm{C}$ contents of between $56 \cdot 1$ and $57 \cdot 1 \mathrm{~mol} \%$.

The type strain is HL $5^{\mathrm{T}}\left(=\right.$ DSM $15072^{\mathrm{T}}=$ UNIQEM U $\left.221^{\mathrm{T}}\right)$.

\section{Acknowledgements}

This work was supported by NWO-RFBR (grant 047.011.2004.010) and RFBR (grants 04-04-48647, 05-04-48058 and 05-04-48064) and by the Program on Molecular and Cell Biology of the Russian Academy of Sciences (RAS).

\section{References}

Brinkhoff, T. \& Muyzer, G. (1997). Increased species diversity and extended habitat range of sulfur-oxidizing Thiomicrospira spp. Appl Environ Microbiol 63, 3789-3796.

Brinkhoff, T., Kuever, J., Muyzer, G. \& Jannasch, H. W. (2005). Genus VI. Thiomicrospira Kuenen and Veldkamp 1972, 253 ${ }^{\mathrm{AL}}$. In Bergey's Manual of Systematic Bacteriology, 2nd edn, vol. 2, part B, The Gammaproteobacteria, pp. 193-199. Edited by D. J. Brenner, N. R. Krieg, J. T. Staley \& G. M. Garrity. New York: Springer.

De Ley, J., Cattoir, H. \& Reynaerts, A. (1970). The quantitative measurement of DNA hybridization from renaturation rates. Eur J Biochem 12, 133-142.

Fennoy, S. L. \& Bailey-Serres, J. (1993). Synonymous codon usage in Zea mays L. nuclear genes is varied by levels of C- and G-ending codons. Nucleic Acids Res 21, 5294-5300.

Kelly, D. P. \& Wood, A. P. (2000). Reclassification of some species of Thiobacillus to the newly designated genera Acidithiobacillus gen. nov., Halothiobacillus gen. nov. and Thermithiobacillus gen. nov. Int J Syst Evol Microbiol 50, 511-516.

Knittel, K., Kuever, J., Meyerdierks, A., Meinke, R., Amann, R. \& Brinkhoff, T. (2005). Thiomicrospira arctica sp. nov. and Thiomicrospira psychrophila sp. nov., psychrophilic, obligately chemolithoautotrophic, sulfur-oxidizing bacteria isolated from marine Arctic sediments. Int J Syst Evol Microbiol 55, 781-786.

Marmur, J. (1961). A procedure for isolation of DNA from microorganisms. J Mol Biol 3, 208-214.

Musto, H., Romero, H. \& Rodriguez-Maseda, H. (1998). Heterogeneity in codon usage in the flatworm Schistosoma mansoni. $J$ Mol Evol 46, 159-167.

Muto, A. \& Osawa, S. (1987). The guanine and cytosine content of genomic DNA and bacterial evolution. Proc Natl Acad Sci U S A 84, 166-169.

Nelson, D. C. \& Jannasch, H. W. (1983). Chemolithoautotrophic growth of a marine Beggiatoa in sulfide-gradient cultures. Arch Microbiol 136, 262-269.
Nishihara, H., Igarashi, Y. \& Kodama, T. (1991). Hydrogenovibrio marinus gen. nov., sp. nov., a marine obligately chemolithoautotrophic hydrogen-oxidizing bacterium. Int J Syst Bacteriol 41, 130-133. Ohtaka, C. \& Ishikawa, H. (1993). Accumulation of adenine and thymine in a groE-homologous operon of an intracellular symbiont. J Mol Evol 36, 121-126.

Ollivier, B., Caumette, P., Garcia, J.-L. \& Mah, R. A. (1994). Anaerobic bacteria from hypersaline environments. Microbiol Rev 58, 27-38.

Oren, A. (1999). Bioenergetic aspects of halophilism. Microbiol Mol Biol Rev 63, 334-348.

Oren, A. (2002). Halophilic Microorganisms and their Environments. Dordrecht: Kluwer.

Pfennig, N. \& Lippert, K. D. (1966). Über das Vitamin $B_{12}$-bedürfnis phototropher Schwefel bacterien. Arch Microbiol 55, 245-256 (in German).

Sørensen, K. B., Canfield, D. E. \& Oren, A. (2004). Salinity responses of benthic microbial communities in a solar saltern (Eilat, Israel). Appl Environ Microbiol 70, 1608-1616.

Sorokin, D. Yu. \& Kuenen, J. G. (2005). Haloalkaliphilic sulfuroxidizing bacteria in soda lakes. FEMS Microbiol Rev 29, 685-702.

Sorokin, D. Yu., Lysenko, A. M., Mityushina, L. L., Tourova, T. P., Jones, B. E., Rainey, F. A., Robertson, L. A. \& Kuenen, G. J. (2001). Thioalkalimicrobium aerophilum gen. nov., sp. nov. and Thioalkalimicrobium sibericum sp. nov., and Thioalkalivibrio versutus gen. nov., sp. nov., Thioalkalivibrio nitratis sp. nov. and Thioalkalivibrio denitrificans sp. nov., novel obligately alkaliphilic and obligately chemolithoautotrophic sulfur-oxidizing bacteria from soda lakes. Int J Syst Evol Microbiol 51, 565-580.

Spiridonova, E. M., Berg, I. A., Kolganova, T. V., Ivanovskii, R. N., Kuznetsov, B. B. \& Tourova, T. P. (2004). An oligonucleotide primer system for amplification of the ribulose-1,5-bisphosphate carboxylase/oxygenase genes of bacteria of various taxonomic groups. Microbiology (English translation of Mikrobiologiia) 73, 377-387.

Takai, K., Hirayama, H., Nakagawa, T., Suzuki, Y., Nealson, K. H. \& Horikoshi, K. (2004). Thiomicrospira thermophila sp. nov., a novel microaerobic, thermotolerant, sulfur-oxidizing chemolithomixotroph isolated from a deep-sea hydrothermal fumarole in the TOTO caldera, Mariana Arc, Western Pacific. Int J Syst Evol Microbiol 54, 2325-2333.

Tourova, T. P., Spiridonova, E. M., Berg, I. A., Kuznetsov, B. B. \& Sorokin, D. Yu. (2006). Occurrence, phylogeny and evolution of ribulose-1,5-bisphosphate carboxylase/oxygenase genes in obligately chemolithoautotrophic sulfur-oxidizing bacteria of the genera Thiomicrospira and Thioalkalimicrobium. Microbiology 152, 2159-2169.

Van de Peer, Y. \& De Wachter, R. (1994). TREECON for Windows: a software package for the construction and drawing of evolutionary trees for the Microsoft Windows environment. Comput Appl Biosci 10, 569-570.

Wood, A. P. \& Kelly, D. P. (1991). Isolation and characterisation of Thiobacillus halophilus sp. nov., a sulfur-oxidising autotrophic eubacterium from a Western Australian hypersaline lake. Arch Microbiol 156, 277-280.

Yoshizawa, Y., Toyoda, K., Arai, H., Ishii, M. \& Igarashi, Y. (2004). $\mathrm{CO}_{2}$-responsive expression and gene organization of three ribulose1,5-bisphosphate carboxylase/oxygenase enzymes and carboxysomes in Hydrogenovibrio marinus strain $\mathrm{MH}-110$. J Bacteriol 186, $5685-5691$. 